УДК 94(4) 006.95+51(091)

https://doi.org/10.33402/zuz.2019-15-17-36

\title{
Юлія ШУСТОВА
}

кандидатка історичних наук, дочентка кафедри допоміжних історичних дисииплін і археографії Російського

держсавного гуманітарного університету, старша наукова співробітниия Науково-досідницького відділу рідкісних книг (Музею книги) Російської державної бібліотеки (Москва, Росія) ORCID 0000-0002-8909-4976 e-mail:shustova@yandex.ru

\section{НЕВІДОМА «АРИФМЕТИКА» УКРАЇНСЬКОГО ВЧЕНОГО ВАСИЛЯ КОРВІН-КВАСОВСЬКОГО В СКЛАДІ КЕНІГСБЕРЗЬКОГО КАЛЕНДАРЯ НА 1730 РІК}

Стаття присвячена невідомій праці з арифметики українського вченого, математика, автора друкованих кириличних календарів Василя Корвін-Квасовського. Він друкував свої календарі в Чернігові і Кенігсберзі. Ці книги містили календарно-хронологічну інформацію на поточний рік, а також включали астрологічні, прогностичні тексти і тексти просвітницької тематики. У власній друкарні в Кенігсберзі Корвін-Квасовьський до складу Календаря на 1730 р. включив посібник для навчання арифметики «Арифметика, чи цифірне вчення». Це перший друкований посібник з арифметики українською мовою українського вченого, вихідця з західноукраїнських земель. В статті робиться спроба реконструкції біографії Василя Корвін-Квасовського. Говориться про його навчання в Кенігсберзькій академії і викладання в Краківському і Празькому університетах. Розглядається його діяльність як автора і видавця календарів, зокрема про видання в 1719 р. Календаря, складеного для «Чернігівського меридіану». Останній період життя Корвін-Квасовського був пов'язаний з Кенігсбергом, де він займав ряд поважних посад, отримав привілей на діяльність власної друкарні, в якій видавав календарі. Загалом відомо три Кенігсберзьких видання календарів Корвін Квасовського - на 1727 і два видання на 1730 pp. (гравіроване і набірне). У статті подається детальний опис набірного Календаря на 1730 р., в якому вміщено «Арифметику». Розглядається «Арифметика, чи цифірне вчення», яка уявляє собою першу частину навчального посібника. Вона складається з п’яти розділів. В першому розглядаються цифри і числа, в наступних подаються правила числення чотирьох математичних дій - додавання, віднімання, множення, ділення. В статті робиться порівняння основних понять в «Арифметиках» Корвін-Квасовького і Леонтія Магницького (Москва, 1703 р.). На підставі аналізу наведених пояснень і прикладів робиться висновок про Василя Корвіна-Квасовського як талановитого педагога, який втілив свій викладацький досвід в підручнику з арифметики. В додатку до статті вперше повністю публікується текст першої друкованої «Арифметики», написаній українською мовою вченим з Дрогобича Василем Корвін-Квасовським.

Ключові слова: Василь Корвін-Квасовський, календарі, історія математики, арифметика, українські стародруки, кирилична друкарня в Кенігсберзі. 
Українська друкована книжкова спадщина починається з виданої у Римі в 1483 р. книги вченого з Дрогобича Юрія Котермака, якого також в документах називають Юрій зі Львова, Юрій з Русі. Будучи професором Болоньского університету, де він викладав курс астрономії, він написав трактати календарно-астрономічного змісту, які нам відомі в рукописах, а один був надрукований - «Прогностична оцінка поточного 1483 р. магістра Юрія Дрогобича з Русі доктора мистецтв і медицини славетного Болонського університету» («Iuducium pronosticon Anni M. CCCC. LXXXIII currentis Magistri Georgii Drohobicz de Russia almi studii Bononiensis artium et medicine doctoris. Feliciter incip») $)^{1}$. До наукового обігу перша друкована книга українського автора була введена лише в 1938 р. і стала предметом ретельного дослідження багатьох вчених. Але у вивченні наукової спадщини українських авторів, вчених, які поширювали знання з природничих і точних наук ще досі лишаються білі плями. Серед таких постатей слід назвати ім'я Василя Корвін-Квасовського, який був професором Празького і Краківського університетів, укладав та видавав календарі, був автором трактатів 3 математики і воєнної архітектури. Друкована спадщина Василя Корвін-Квасовського календарі, надруковані у Чернігові і Кенігсберзі-лишається малодослідженною. Саме тому перший друкований посібник з арифметики українського автора, який увійшов до складу одного з Кенігсберзьких календарів, був невідомим в науці.

Про Василя Корвін-Квасовського відомо вкрай небагато. Не знаємо дати його народження. Про його походження з Дрогобича вперше вказав Д. Олянич в статті про пам'ятки 3 минулого українського культурного життя в Кенігсберзі ${ }^{2}$, також це відзначали Г. Коляда і Я. Ісаєвич в розвідці про друкарську справу на західноукраїнських землях ${ }^{3}$. Відомостей про його походження, батьків і початкову освіту КорвінКвасовського немає. Я. Ісаєвич в 2004 р. зробив припущення, що початкову освіту він здобув у дрогобицькій парафіяльній школі ${ }^{4} .18$ квітня 1715 р. він вступає до Кенігсберзької акдемії «Альбертіни», про що зберігся запис в реєстрі закладу: «Roxolanus Basil Corvin, Graecae olim religionis, iam reformatae, iur., gratis inscriptus est» ${ }^{5}$.

Здобувши освіту в Кенігсберзькій академії, Корвін-Квасовський він викладав точні та природничі науки в кращих європейських університетах того часу. Він був вчителем вільних мистецтв і філософії, професором математики і військової архітектури спочатку в Краківському, а потім в Празькому університетах. Про це Корвін-Квасовський повідомляє в першому соєму виданні: «Въ Пре Славной Академїи Краковскои, а потомъ Празкои наук вызволеныхъ и философїи оучителА

${ }_{1}^{1}$ Ісаєвич Я. Д. Юрій з Дрогобича. Українське небо. Студї̈ над історією астрономї̈ в Україні: зб. наук. пр. Львів, 2014. С. 493-494, 496-501.

2 Олянчин Д. Пам'ятки із минулого українського духовно-культурного життя в Кенігсберзі. Науковий збірник в 30 річницю наукової праці проф. д-ра Івана Огієнка. Варшава, 1937. № 39. C. 105.

3 Коляда Г. І., Ісаевич Я. Д. Друкарська справа на західноукраїнських землях (XVI-XVIII ст.). Книга і друкарство на Україні. Київ: Наукова думка, 1965. С. 64.

${ }^{4}$ Ісаєвич Я. Д. Дрогобич у XVII-XVIII ст.: 3 джерел про побут і культуру міського населення. Дрогобицький краєзнавчий збірник. Дрогобич, 2004. С. 202.

5 Die Matrikel der Albertus-Universität zu Königsberg in Preussen. Pr. II. Band: Die Immatrikulationen von 1657-1829. Leipzig: Duncker \& Humblot, 1912. S. 289. 
математики и архитектури военной Професора Школь Божьего Тъла на Казъмъръ сенїора въ Шкламњру директора» ${ }^{6}$.

У 1718 р. Василь Корвін-Квасовський видав «Греческій, римскій и еврейскій календарь», як зазначено на титульному аркуші, в «широть российскаго града Черниьгова». В «Предисловіи» він писав, що підніс свою працю архієпископу Чернігівському і Новгород-Сіверському Антонію Стаховському «изо всех учений математических наименшую часть календариографею», яку він хотів надрукувати в єпископській чернігівській друкарні «во весь мир россиский посылати дерзаю» ${ }^{\text {. }}$ Сьогодні відомий єдиний примірник цього видання, що зберігається в Бібліотеці Російської академії наук в Санкт-Петербурзі.

Чернігівська Троїцько-Іллінська друкарня на початку XVIII ст. була великим видавничим центром, в якій працювали професійні друкарі, талановиті гравери, також вона мала власну папірню8. Календар Василя Корвін-Квасовського суттево відрізняється від чернігівських видань того часу. Він надрукований дуже недбало, всі лінії викривлені, в книзі досить дрібний шрифт, поганий папір, філіграней не видно. В ній також міститься одна заставка, яка жодного разу не повторювалася в виданнях чернігівської друкарні. Т. Н. Каменєва припустила, що книга була надрукована або приватним порядком в друкарні Троїцько-Іллінського монастиря, або у власній друкарні Квасовського. Вона зазначила, що, не зважаючи на те, що календар присвячений чернігівському єпископу Антонію Стаховському (в передмові він названий «моим патроном и благодетелем»), він був здивований виходом у світ книги і скаржився гетьманові України Івану Скоропадському на самостійні видання Квасовського, що вийшли з ім'ям єпископа ${ }^{9}$. Вірогідно, не здобувши підтримки у виданні своєї праці в Чернігові, Квасовський вирішує створити свою друкарню. Зробити це в Росії було неможливо, та й за ії межами в великих містах, де вже існували друкарні, друкувати кириличні книги було досить важко. На початку XVIII ст. календарі в Росії друкувалися в Москві і Києві. Зацікавленість у виданні календарів проявляв цар Петро І. Можливо тому Корвін-Квасовський вирішив скласти друкар «по меридиану и широть» Чернігова.

У 1721 р. Василь Корвін-Квасовський в Данцигу придбав частину друкарні Павла Патера (Paulus Pater). Це були матеріали друкарні Іллі Копієвського - декілька наборів пунсонів і матриць. Під час перебування в Данцигу Копієвський намагався налагодити видання календарів для Росії спільно з Павлом Патером. Однак цей проєкт не був реалізований. Павло Патер видавав книги латинськими шрифтами, а кириличні ним так і не були використані. Пунсони й матриці Копієвського і придбав Квасовський для реалізації свого задуму видання календарів кириличним шрифтом. Тексти календарів він писав сам, користуючись різними джерелами і роблячи самостійно астрономічні розрахунки, а також писав до календарів супутні тексти.

${ }_{6}$ Греческий, римский и еврейский календарь на лето Господа нашего Иисуса Христа 1719. [Чернигов, 1718]. Тит. арк.

7 Быкова Т. А., Гуревич М. М. Описание изданий, напечатанных кириллицей: 1689 - январь 1725 г. Москва; Ленинград: Изд-во Акад. наук СССР, 1958. № 119. С. 207.

8 Каменева Т. Н. Типография на Левобережье Украины. 400 лет русского книгопечатания. 1564-1964. Москва: Наука, 1964. С. 222.

9 Там само. С. 223. 
Квасовський прибуває до Кенігсберзі, де стає таємним секретарем короля Пруссії і «присяжним транслятором», тобто офіційним перекладачем з російської та польської мов. Разом з придворним радником Вітором Квасовський вербував на території Великого князівства Литовського вояків для служби в прусській армії. Саме це забезпечило його широкими зв'язками при прусському королівському дворі i фактичне призначення на посаду таємного радника з винятковим привілеєм бути офіційним перекладачем з російської та польської мов.

Йому вдалося отримати право завести свою друкарню. 11 листопада 1727 p. Корвін-Квасовський отримав привілей короля Фрідріха Вільгельма I на влаштування друкарні для видання книг польською, російською, слов'янською, німецькою і латинською мовами. Перший календар, надрукований у друкарні Василя Корво-Квасовського, вийшов 1727 р. Це був Календар на 1727 р. ${ }^{10}$ Можливо, він був надрукований ще до отримання офіційного права видавати книги. Наступного року Квасовський випустив два видання календарів на 1730 р. - одне гравіроване на міді, друге - набірне. Вони відрізняються художнім оформленням (в мідьориті присутні ілюстрації), а також змістовно. Текст гравірованного видання опублікував Д. О. Ровінський ${ }^{11}$. До складу набірного видання Календаря на 1730 р. ${ }^{12}$ Василь Корвін-Квасовський включив свою Арифметику - посібник для початкового вивчення чотирьох математичних дій.

Василь Корвін-Квасовський опікувався православною громадою Кенігсберга. В 1726 р. він зміг здобути офіційний дозвіл влади Кенігсберга на обладнання домової церкви в своєму будинку, а в наступному році - дозвіл на будівництво православної каплиці. 3 Брестського монастиря Квасовський запросив трьох ченців, які здійснювали в Кенігсберзі регулярні богослужіння.

У Російському державному історичному архіві збереглося прохання причту і парафіян «Кенігсберзької православної церкви» на ім’я імператора від 17 травня 1728 р. В ньому докладно описано пільгові умови, надані прусським урядом православним у Кенігсберзі, повідомляється про дозвіл прусської влади на будівництво в місті православної церкви, викладається скарга на певні економічні труднощі і прохання прийняти Кенігсберзьку православну громаду під протекцію Російської держави, допомогти побудувати будівлю храму, забезпечити прихід церковним начинням, а причт - платнею. Цей документ підписали ігумен Гервасій Рудвицький, ієромонах Серафим Радишевич, староста Кенігсберзької церкви Федот Фетотовіча і Василь Квасовський.

Прохання розглядалося у Святійшому Синоді 3 червня 1728 р. i 20 червня було направлено до Колегії закордонних справ російського уряду. Далі сліди його губляться, а справа подальшого розвитку не отримала. Православний храм в Кенігсберзі в ті роки так і не був побудований. Ігумен Гервасій $з$ побратимами повернулися назад в Брест. Квасовський вмовив ієромонаха того ж монастиря Антонія Пашковського переїхати в Кенігсберг їм на зміну. Він проводив богослужіння і після смерті Квасовського в 1736 р., але фінансової підтримки у громади не було. Антоній Пашковський звернувся до прусського уряду з проханням про підтримку, але король Фрідріх

\footnotetext{
${ }^{10}$ Календарь на 1727 год. Кенигсберг: Тип. Василия Корвен Квасовского, [1726].

${ }^{11}$ Ровинский Д. А. Русские народные картинки. Санкт-Петербург: Имп. Акад. наук, 1881. Кн. 2: Листы исторические, календари и буквари. № 666. С. 434-455.

${ }^{12}$ Календарь на 1730 год. Кенигсберг: Тип. Василия Корвен Квасовского, [1729].
} 
Вільгельм I, хоча й хотів з політичних міркувань підтримати православну церкву в Пруссії, але у виділенні грошей відмовив. Незабаром православні богослужіння в Кенігсбергу припинилися ${ }^{13}$.

Таке опікування православною спільнотою в Кенігсберзі дозволяє стверджувати, що Василь Корвін-Квасовський належав до православної церкви.

Після смерті Корвін-Квасовського його друкарня збанкрутувала. Її придбав за безцінь Кенігсберзький книгопродавець Кантер ${ }^{14}$.

Помер Василь Корвін-Квасовький в Кенігсберзі в 1736 р.

Набірний календар на 1730 р. вперше в бібліографії був описаний В. С. Сопіковим у 1821 р., з наведенням тексту титульного аркуша і зазначенням формату - «в $4\rangle^{15}$. Такий самий опис 3 доповненням відомостей про обсяг книги (20 аркушів) привів П. М. Строєв, описуючи примірник з бібліотеки Іверського Валдайського монастиря ${ }^{16}$. Короткий опис «Календаря греко-русского» навів В. М. Ундольский, повідомлюючи про примірники з бібліотек О. І. Кастерина й Імператорського Московського товариства історії та старожитностей російських («Императорского Московского общества истории и древностей российских») ${ }^{17}$. «Календарь греко-русский» коротко описав I. П. Каратаєв, він навів примірник з бібліотеки Академії наук в Санкт-Петербурзі ${ }^{18}$. Бібліографи XIX ст. дали лише короткий опис книги, проте повного опису із зазначенням iіi змісту, оформлення ще досі немає. Також немає джерелознавчого дослідження цього календаря.

Кенігсберзький Календар на 1730 р. Василя Корвін-Квасовського виданий двокольоровим друком, титульний аркуш - в рамці з виливних прикрас, в кінці книги ксилографічна кінцівка стародрукованого стилю. Внизу сторінок поакрушно містяться авторські позначки, надруковані кіновар'ю (перші шість) і чорною фарбою: «У 1730», «3 1730», «D 1730», «E 1730», «F $1730 », ~ « \mathrm{G} 1730 », ~ « \mathrm{H} 1730$ », « I $1730 »$, « До 1730».

На титульному аркуші наводиться назва книги і вихідні дані: «Календаръ, грекорускіи по стилю юльанскому на льто господне 1730, потомъ $\overline{\mathrm{G}}$ льта 1731 на льть 100. По чину и правленїю седми планетъ паки на первое возвращающїися вь которомъ, кромъ

\footnotetext{
${ }^{13}$ Бирюков Г. Начало русского книгопечатания в Кенигсберге. URL: https://ruskline.ru/analitika/2009/11/12/nachalo_russkogo_knigopechataniya_v_kenigsberge/ (дата звернення: 05.11.2020).

${ }^{14}$ Губин А. Б. Православие в Восточной Пруссии (Записки). Запад России. 1994. № 4 (12). C. 7-19.

${ }^{15}$ Сопиков В. С. Опыт российской библиографии, или Полный словарь сочинений и переводов, напечатанных на славенском и российском языках от начала заведения типографий, до 1813 года. Санкт-Петербург: В типографии Департамента внешней торговли, 1821. Ч. 5. № 12920. С. ; Сопиков В. С. Опыт российской библиографии. Санкт-Петербург, 1906. Ч. 5. № 12920. C. 106.

${ }^{16}$ Строев П. М. Описание старопечатных книг славянских, служащее дополнением к описаниям библиотек графа Ф. А. Толстова и купца И. Н. Царского. Москва: Тип. С. Селивановского, 1841. № 155. С. 239.

17 Ундольский В. М. Каталог славяно-русских книг церковной печати библиотеки А. И. Кастерина. Москва: О-во истории и древностей росс., 1848. № 779; Ундольский В. М. Очерк славяно-русской библиографии. Москва: Моск. публичный и Румянцев. музеи, 1871. Стб. 180. № 1779.

${ }^{18}$ Каратаев И. П. Хронологическая роспись славянских книг, напечатанных кирилловскими буквами. 1491-1730. Санкт-Петербург: Тип. Акад. наук, 1861. № 1572. С. 202.
} 
различнихъ, куриезнихъ, гражданскихъ, господарскихъ, астрологическихъ вещеи, краткое воведенїе во ариөметику, зъ придаткомъ, наукы $\omega$ робленю различныхъ домашнимъ коштомъ Фльиковъ, на различнїе бользни и дефекта учиненнїи, чрезъ М: Василић Корвъна Квасовского наукъ вызво: философїи и математики учителА, его ко: ве: пру: таиного секретара и упривелованого типографа. Напечатанъ въ Кролевци Прускомъ, въ его власнои друкарнђ». На звороті титульного аркуша вказано ім’я гетьмана України Данила Апостола, якому автор присвячує книгу: «Ясне велможному пану п. Даніилу Апостолу, его їмператорского вел: воикъ малороссїикихъ, запорогскихъ, и шбоихъ сторонъ Днепра Богомъ даному Богомъ хранимому гетманоу бодрому въ Фтечествъ $\bar{G}$ врагъ заступнику храброму и непреодольнному во бранехъ Ахиллесу второму мисленнихъ лвовъ Данїилу укротителю крђпкому Самсону мира, здравїя, благополучї^, на враговъ побъди $\bar{G}$ Бога вънца въчнаго авторъ усердно желаетъ». В тексті присвяти гетьман і українська нація порівнюються з багатьма античними богами і героями.

Для Василя Корвін-Квасовського було важливо підкреслити, що календарі, які він видавав, призначались перш за все для поширення серед українського народу. Про це свідчать присвяти чернігівського календаря архієпископу Чернігівському і НовгородСіверський Антонію Стаховському, календаря на 1730 р. гетьману України Данилу Апостолу. Календарі написані українською книжною мовою, що також говорить про те, що вони призначались перш за все для розповсюдження в українських землях.

Календарна частина починається словами «Во имя Їисусово». Далі вказуються ери - скільки років минуло від важливих подій - від різдва Ісуса Христа, від створення світу «по греческимъ хронографомъ», «по римскимъ», «по жыдовскимъ», від початку чотирьох монархій - Вавилонської, Перської, Грецької і Римської, від введення юліанського і григоріанського календарів. Зазначено про те, скільки років минуло від найважливіших винаходів: від винаходу пороху, від початку друкарства, «Туба оптичнаго перпендикула до часовъ» (мається на увазі винахід Християном Гюйгенсом маятникових годинників, забезпечених спусковим механізмом), а також відкриття Нового Світу. У числі російських подій відзначено скільки років минуло від народження імператора Петра II, його коронації, « $\overline{\mathrm{G}}$ начала флота Россїи», від Полтавської битви, від початку гетьманства Данила Апостола.

Розворот сторінок присвячено одному з дванадцяти місяців і складається з чотирьох стовпців на лівому розвороті і одного - на правому. У першому стовпці міститься короткий Місяцеслов із зазначенням недільних читань з Свангелій і Апостола (в шапках стовпця вказується назва місяця, кількість днів і рік - 1730); у другому - «Течение луны» (проходження місяця за знаками зодіаку); «Б̄ зазначаються астрономічні, астрологічні і погодні явища. У наступному стовпці протягом усіх 12 розворотів надрукована «Ариөметика, или цифьрное ученїе»- короткий підручник арифметики. Наступний стовпець, що становить всю сторінку, - «Гражданскїи господарскїи календаръ на льтъ 100 учиненїи, и паки на первое возвращающїисА». Текст «Арифметики» и «Гражданского хозяйственного календаря» друкується і на наступних сторінках видання, після завершення календарної частини, розміщуючись в двох стовпцях: «Континуациа на 100 льт календара» і «Континуациа Ариөменики». Після цього надруковано «Прогностикъ генералнїи на льто господние 1730», який розміщено в такій самій таблиці. У місяцеслові навпроти кожного числа місяця вказані дні пам'яті святих і найважливіші церковні свята, включаючи рухомого циклу. У цьому ряду виділяються дві дати. Астрономічна подія 1 травня 1730 р. - «Явленїе на небе» і 
в кінці місяцеслова - історичне - після 31 грудня надруковано повідомлення про день коронації Петра II, без зазначення дати: «NB. Богомъ данного монарха усероссїискаго Петра II коронациа». Коронація Петра II відбулася 25 лютого 1728 р.

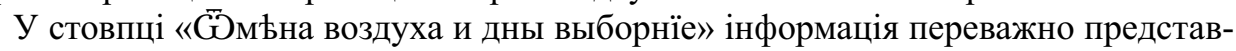
лена у вигляді умовних позначень, легенда яких представлена на початку календаря. У їх числі астрономічні явища (знаки зодіаку, планети, фази місяця та ін.); передбачення (дні нещасливі і дуже нещасливі), дні сприятливі для різних господарських робіт («дрова на будинокь», тобто для будівельних робіт), для сільськогосподар-

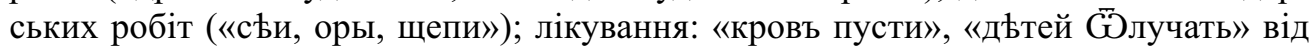
грудей; способи лікування: «флегму чистъ декоктомъ, пьллюлями, електуарїемъ; маленхолью - сокомъ, травами, холеру проносомъ, пъллюлями, декоктомъ, травами, сокомъ, електуарїемъ», «сангвънъстомъ [...] холерикомъ [...] маленхолькомъ руду кидатъ часъ 4 брїи», прийом проносних («проносное въ пьгулкахъ»), блювотних і закріплюючих засобів тощо); гігієни («волоси стричъ», митися в бані).

Прогноз погоди вказується словесно. Наприклад, на січень місяць для різних днів наводяться такі погодні характеристики: «мЂрное зимно, ненастно, снЊгъ, мерна зима, ветер, ясно, погодное небо, вътеръ мокрїи, снегъ, морозъ, туманно и до вътру склонно», на лютий - «снегъ и облачно, привътряно раномъ, пасмурно и солнечное сиянїе, тепляи, дождъ або снегъ, ветер, мороз, вътрянго и мало С̈Элигло, ясно, ночы яснїе, морозъ великъ, вътеръ, туманъ, переменно солнечное сиянїе, въ ночи морозъ, пасмурно, снъжно». Прогнози погоди в календарях XVIII ст. були практично обов'язковими розділами і мали великий попит у читачів.

Розділ календаря «Гражданскїи господарскїи календаръ на льтъ 100 учиненїи, и паки на первое возвращающїисА» містить астрологічну і календарно-хронологічну інформацію. Починається цей розділ з характеристики семи планет - Сатурна, Юпітера, Марса, Сонця, Венуса (Венери), Меркурія і Місяця, - які керують тим чи іншим роком, відзначається як кожна планета впливає на погоду в році (за сезонами і за місяцями), на виноробство, рибальство, здоров'я людей та військові дії. Є таблиці для визначення планети року по колу сонця і вруцеліту. Таким чином, читач міг визначити яка планета керує конкретним роком і використовувати викладені прогностичні відомості протягом ста років.

Далі наводяться невеликі статті медичного і прогностичного змісту: «G кровопусканїю»; «Прогностик господарскїи до калїндара на 100 льтъ», де містились різноманітні прикмети; «GD планетнихъ днехъ и часъхъ, котора^ которимъ днемъ и часомъ владъетъ»; «GD часахъ днА и ночи въ которую которах планета власть и силу имъетъ»; «GD затмЂнїяхъ» (повідомляється про сонячні і місячні затемнення в 1731-1740 рр.); «Способ рабленА Фльивовъ, и скутки Фних» (виготовлення різних олій і їх застосування від різноманітних хвороб).

Ще один розділ Календаря на 1730 р. - «Прогностикъ генералнїи, на льто господние 1730». Це практично обов'язкова частина календарів XVIII ст., де подається характеристика пір року, передбачення погоди на рік, про сільськогосподарські роботи, лікування хвороб, війни. Аналогічні статті присутні, наприклад, в київських виданнях календарів 20-30-х pp. XVIII ст. ${ }^{19}$ «Прогностик» на 1730 р. містить розділи «GО зимЂ»,

${ }^{19}$ Бондар Н. Рідкісні календарні видання першої половини XVIII ст. Києво-Печерського друку з фондів Національної бібліотеки України імені В. І. Вернадського. Украӥнське небо 2. 
«GD веснь», «G льту», «G есени», «GD съянїю и саженїю» (про сприятливі дні для посіву, посадки і пересадки різних культур, зокрема вівса, ячменю, конопель та льону), «Избранїе знаковъ и временъ пригоднихъ до лькарствъ» (про лікування таких хвороб як холера, флегма і меланхолія), «Зодїя содержатъ члены» (про заступництво знаків зодіаку органам і частинам тіла людини, так звана зодіакальна людина), «Лњкарство приниматъ» (коли приймати «проносне, рвотное, слабителное, крђпителное»), «G бользнАхъ» (про смирення християнина перед хворобою і небоязні смерті, перелік небезпечних хвороб на рік), «Брань или миръ», «G затмђнеїяхъ» - місячному затемненні 23 лютого і частковому сонячному 4 липня.

У переліку таких традиційних для календарів розділів, які друкує Василь КорвінКвасовський в Календарі на 1730 р., він розміщує текст написаного ним підручника з арифметики. Календарі в Західній Свропі в XVII - першій чверті XVIII ст. мали не тільки довідковий, а й просвітницький характер. Саме тому Василь КорвінКвасовський, який був професором математики, вважає доцільним спробувати використати календарні сторінки для того, щоб опублікувати свій твір з арифметики «Ариөметика, или цифьрное ученїе». Це короткий компілятивний твір про основи арифметики, написаний українською мовою.

Кириличних друкованих навчальних посібників для навчання математики було дуже мало. Першим друкованим підручником з арифметики слов'янською мовою було складене Іллею Копієвським «Краткое и полезное руковедеїе во аритметыку, или въ Амстердамі в 1699 р. у друкарні Яна Тессінга. Однак ця книга, надрукована тиражем 3350 примірників на замовлення архангельських купців Філатьєвих, ними викуплена не була. Книги Копієвський надіслав у Москву з проханням до Петра I посприяти в питанні повернення йому грошей за роботу ${ }^{20}$. Але книга в Росії не отримала поширення $^{21}$. Фундаментальна праця Леонтія Магницького «Арифметика», що вийшла на Московському друкованому дворі в 1703 р. була вельми дорогою книгою, а її розділи включали не тільки арифметику, але й інші науки, необхідні для навчання в школі навігації, для якої підручник призначався.

«Арифметика» Василя Корвін-Квасовського залишилася непоміченою працею i, як i «Арифметика» Іллі Копієвського, не зробила істотного впливу на математичну освіту ні в Росії, ні в Речі Посполитій. Але, на відміну від книги Копієвського, ця праця залишається не дослідженою і обійденою увагою як істориків математики i науки, так і істориків педагогіки та книг з культури. Ця праця українського вченого є

Студї̈ над історією астрономії в Україні: зб. наук. пр. Львів, 2016. С. 652-655; Шустова Ю. Э. Киевские издания Календарей 30 -х годов XVIII в. из собрания Российской государственной библиотеки как источники по истории экологических и естественно-научных знаний. Человек и природа: История взаимодействия, источники и информачионные ресурсы, визуальные образы и исследовательские практики: материалы XXX Междунар. науч. конф., Москва, 25-26 апр. 2017 г. Москва, 2017. С. 40-41.

${ }^{20}$ Пекарский П. П. Наука и литература в России при Петре Великом. Санкт-Петербург: издание Товарищества «Общественная польза», 1862. Т. 1: Введение в историю просвещения в России XVIII столетия. С. 14-15, 526-527.

${ }^{21}$ Депман И. Я. История арифметики. Москва: Просвещение, 1965. С. 97-98. 
першим підручником з арифметики, написаний українською мовою, досить цікавий за змістом і, безумовно, вимагає окремого дослідження.

На початку цієї праці дається визначення арифметики як науки: «Ариөметика, естъ искуство щота, сиестъ: налогъ числа, или вещеи изчисляемихъ, пособїемъ нькїихъ характировъ скоро, и кратко изчисляти. С્ Бтуду и прозванїя своего начало имъетъ: чтобо грекомъ ариөмосъ тожъ, славяномъ щотъ, а нинъшнимъ россїаномъ цифьръ, $\overline{\mathrm{G}}$ цифри, ея же харахтиръ». Рукопис «Арифметики» Корвін-Квасовського складався 3 трьох частин: «первая часть о числьхъ вь цълихъ, вторая долАхъ, третая о правылахъ». У складі календаря на 1730 р. він надрукував тільки першу частину. Закінчує «Арифметику» автор післямовою («Увђщанїе»), в якій говорить, що якщо читачам буде цікаво, то в подальшому він продовжить друкувати свої праці, так як у нього готова «Арифметика» повністю. Крім того в рукописах у нього були підготовлені також підручники з «Математики» і «Архітектури військової» («На сеи годъ доволно, аще плоды въ людяхъ сихъ трудовъ увидимъ, не умедлимъ обширне и болше написать, бо есть въ готовости, цъла Ариөметика, Математика и Архитектура военна»). На жаль, Корвін-Квасовський не здійснив свої задуми, нам невідомі видання Квасовського після 1730 р. Також невідома доля його рукописної спадщини.

«Ариөметика, или цифьрное ученїе» Корвін-Квасовського починається з першої частини «G числьхъ въ цълихъ», яка складається з наступних розділів: «О изчисленїю», «G сложенїю, аданцїи», «G вичитанїю или субтракцїи», «G умноженїю, мултиплькацїи», «GО дъленъю або дивъзїи». Це була традиційна для того часу схема розділів арифметики. Так, для порівняння, Леонтій Магницький в «Арифметиці», надрукованій в Москві у 1703 р. також наводить п'ять розділів цієї науки («имђетъ пределеній плть») і подав їхні назви грецькою, латинською і слов’янською мовами. Для порівняння 3 текстом Корвін-Квасовського наводимо лише латинські та слов'янські еквіваленти: «numeratio - счисленїе, additio - сложенїе, subtractio вычитанїе, multiplicatio - оумноженїе, divisio - дьленїе»).

Корвін-Квасовський подає досить стисле визначення цілих чесел: «Числа въ цђлихъ суть, которїе на доль, или на частици нераздђленни суть».

Розділ «О изчисленїю» присвячений опису і характеристиці цифр і чисел, а починається з образного порівняння вивчення їх в арифметиці з вивченням букв у букварі: «"ко букваръ первїе познан" писм"нъ, потомъ чтенї", сице и щотъ первїе познанї" харахтировъ, а потомъ тими жъ харахтирамы, скораго и краткаго изчисленї" научаетъ». Автор використовує таблиці для кращого вивчення чисел, в яких подаються числа від одиниць до триліонів (в «Арифметиці» Леонтія Магницького - до квадріліонів).

В розділах про арифметичні дії Корвін-Квасовський подає визначення кожної дії, детально пояснює, як виконувати розрахунки на прикладі великих чисел, тобто складати, віднімати, множити і ділити в стовпчик, а також як перевірити правильність кожної дії. Тобто передбачалося, що найпростіші арифметичні дії читачеві знайомі i, принаймні, таблицю додавання він знає. В той же час, в розділі про множення наводиться таблиця множення Піфагора від одного до десяти.

Визначення арифметичних дій у Корвін-Квасовьського будуються власне 3 подання суті тої чи іншої дії і прикладів для кращого їх розуміння. В «Арифметиці» Леонтія Магницького ці визначення формулюються інакше й не включають пояснювальні приклади. 


\begin{tabular}{|c|c|c|}
\hline $\begin{array}{l}\text { Арифметич- } \\
\text { на дія }\end{array}$ & $\begin{array}{c}\text { «Арифметика» Леонтія Маг- } \\
\text { ницького (Москва, 1703) }\end{array}$ & $\begin{array}{c}\text { «Арифметика» Василя Корвін- } \\
\text { Квасовського (Кенігсберг, } \\
\text { 1729) }\end{array}$ \\
\hline Додавання & $\begin{array}{l}\text { Аддицїо или сложенїе есть, дву } \\
\text { или многихъ числъ во едино } \\
\text { собранїе, или во единъ перечень } \\
\text { совокупленїе. }\end{array}$ & $\begin{array}{l}\text { Сложенїе есть многихъ числь еди- } \\
\text { наго вида, вь многихъ перчн"хъ, } \\
\text { во единъ перечень собранїе } \\
\text { Фднаго вида: тоесть подобную } \\
\text { вещъ с подобною себъ, и писатъ } \\
\text { и слагатъ: напримьръ рубль зъ } \\
\text { рублемъ, ефимки со ефимками, } \\
\text { золотие со золотими. }\end{array}$ \\
\hline Відніма & $\begin{array}{l}\text { Субтракцїо, или вычитанїе } \\
\text { есть, имже малое число, из } \\
\text { болшагш вычитаемъ, и излишнее } \\
\text { Фблвллемъ. }\end{array}$ & $\begin{array}{l}\text { Вичитанїе, есть меншаго числа, } \\
\text { зъ болшаго } \overline{\mathrm{G}} \text { "тїе, по которомъ } \\
\overline{\mathrm{G}} \text { "тю нужда знать, сколко вь } \\
\text { шсталихъ будетъ. "ко } 2 \text { вичитав- } \\
\text { ши зъ } 4 \text {, останетъ } 2 .\end{array}$ \\
\hline Мно & $\begin{array}{l}\text { Оумноженїе естъ, им же что в } \\
\text { числахх оумножаемъ или коли- } \\
\text { кимъ вещемъ по множеству ин- } \\
\text { ныхъ вещей раздаемъ: и количе- } \\
\text { сто ихъ ыисломъ показуемъ. }\end{array}$ & $\begin{array}{l}\text { Умноженїе: есть единаго числа, } \\
\text { чрезъ другое число помноженїе, } \\
\text { напримъръ: трижди, по трижди, } \\
\text { будеть } 9 .\end{array}$ \\
\hline Ділення & $\begin{array}{l}\text { Дьленїе ест, им же болшее число, } \\
\text { или перечень на равныА части } \\
\text { меншимъ раздълАемъ, } \overline{\mathrm{G}} \text { нихъ } \\
\text { же едину, числомъ же показуемъ. }\end{array}$ & 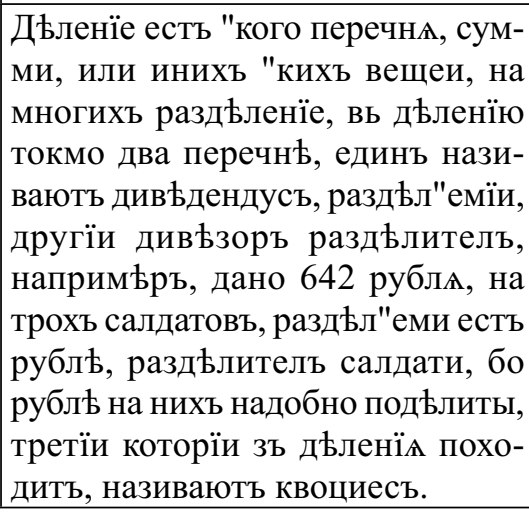 \\
\hline
\end{tabular}

Корвін-Квасовський був талановитим педагогом. Його теоретичні викладки $\mathrm{i}$ пояснення, як потрібно додавати чи множити, віднімати чи ділити лаконічні, чіткі і водночас зрозумілі. Незважаючи на те, що прикладів наводиться рівно стільки, щоб пояснити специфіку процесу математичних розрахунків, процес навчання за таким підручником був максимально ефективним.

Василь Корвін-Квасовський присвятив свою друкарську діяльність видавництву календарів, які він складав в кращих західноєвропейських традиціях. Вони стали взірцями для календарів, що будуть друкуватися протягом XVIII ст. в друкарнях Києва, Санкт-Петербурга та Москви. Крім календарної, астрономічної, астрологічної інформації український вчений друкував на сторінках свої твори: в календарі на 1727 p. - короткий домашній лікарський порадник «Аптека домова», в календарі 
на 1730 р. - першу частину «Арифметики». На жаль, плани про подальше видання своїх математичних творів Квасовський не втілив у життя. «Арифметика, чи цифірне вчення» є першим підручником з арифметики, написаним українською мовою ученим-математиком, талановитим педагогом, вихідцем з західноукраїнських земель і заслуговує подальшого ретельного дослідження на міждисциплінарному рівні.

Додаток 22

Арифметика або циифірне вчення. Календар на 1730 р. Кролевеч [Кенігсберг: друкарня Василя Корвін-Квасовського, 1729].

\section{Ариөметика, или цифњрное ученїе}

Ариөметика, естъ искуство щота, сиестъ: налогъ числа, или вещеи изчисляемихъ, пособїемъ нЊкїихъ характировъ скоро, и кратко изчисляти. Б̄ туду и прозванїя своего начало имъетъ: чтобо грекомъ ариөмосъ тожъ, слав"номъ щотъ, а нинъшнимъ россїаномъ цифьръ, $\overline{\mathrm{G}}$ цифри, ея же харахтиръ.

РаздЂл"етъс" на три части: перва" часть о числьхъ вь цЊлихъ, втора" въ дол"хъ, трета" о правылахъ."

\section{Часть 1.}

G) числьхъ въ цђлихъ.

Числа въ цђлихъ суть, которїе на доль, или на частици нераздђленни суть:

Числъ цьлихъ п"ть выдовъ есть: изчисленїе нумерацио, сложенїе адацїо, вычитанїе субтракцїо, умноженїе мултиплькацїо, дленїе дивђзио.

\section{О изчисленїю.}

«ко букваръ первїе познанї" писм"нъ, потомъ чтенї", сице и щотъ первїе познанї" харахтировъ, а потомъ тими жъ харахтирамы, скораго и краткаго изчисленї" научаеть.

Таковыхъ естъ дес"тъ, $\bar{G}$ варваръ кь намъ принесеннихъ 1234567890.

Первїе дев"ть нарицаютьс" чыслителнїе понеже вс"кїи толко по одиножди держитъ, на коликомъ мъсть $\overline{\mathrm{G}}$ перваго положенъ: напримъръ унум 1 одынъ; 2 дуо два, три" 3 три, 4 кваторъ чотиры, 5 квьнкве п"ть, 6 сексь шесть, 7 септемъ седмъ, 8 окто осмъ, 9 новемъ, дев"т. 0, цифра ноль, нъчого, сама собою не силна не числителна, развђ числителному присовокупленна, и тогда силу его дес"тю помнажаетъ, напримьръ, до 1 присовокупленна, держит дес"ть, до 2 - дваиц"ть, до 3 - трїиц"ть, до 4 - сорокь, до 5 - п"тдесть, до 6 - шестьдес"ть, до 7 - сьмъдес"ть, до 8 - осмъдес"ть, до 9 - дев"тьдес"ть, а когда до 1 двь цифри приложишъ, то будетъ сто, а когда - 000 тис"ча, кагда 0000 - дес"ть тис"чеи, когда 00000 - сто тис"чеи, когда 000000 - будеть мълъонъ, когда 7 цифръ - дес"ть мълЂоновъ, 8 цифръ - сто мъльоновъ. Пароча" тоежъ разумъи и о другихъ характирахъ: $2,3,4,5,6,7,8,9$. Цифри вс"гди 3 правои руки присовокупл"ютъс" числителнимъ харахтирамъ того дл", во вс"комъ перечнъ первїи нумеръ, тои називаетъс" которїи наипосльднеишїи, $\overline{\mathrm{G}}$ правои руки, вторїи по немъ сльдующїи, и про.: “ко в семъ перечнъ: 1730 первї̈и естъ 0, вторїи 3, третїи 7,четвертїи и остатнїи 1. Вс"кїи харахтиръ на первомъ мъсть положенъ болшои сили не имђетъ, “ко самъ собою естъ, втори держитъ дес"ткы, третїи сотнъ, четвертїи

${ }^{22}$ В публікації «Арифметики» Василя Корвін-Квасовського текст передається буква в букву, зі збереженням пунктуації. 
тис"чъ. Вышшереченнїи перечень такъ изчисл"ють: тис"ча сьмсоть триц"ть. Лудшаго познанїА сили въ перечн"хъ, внимаи посльдующїе таблицъ:

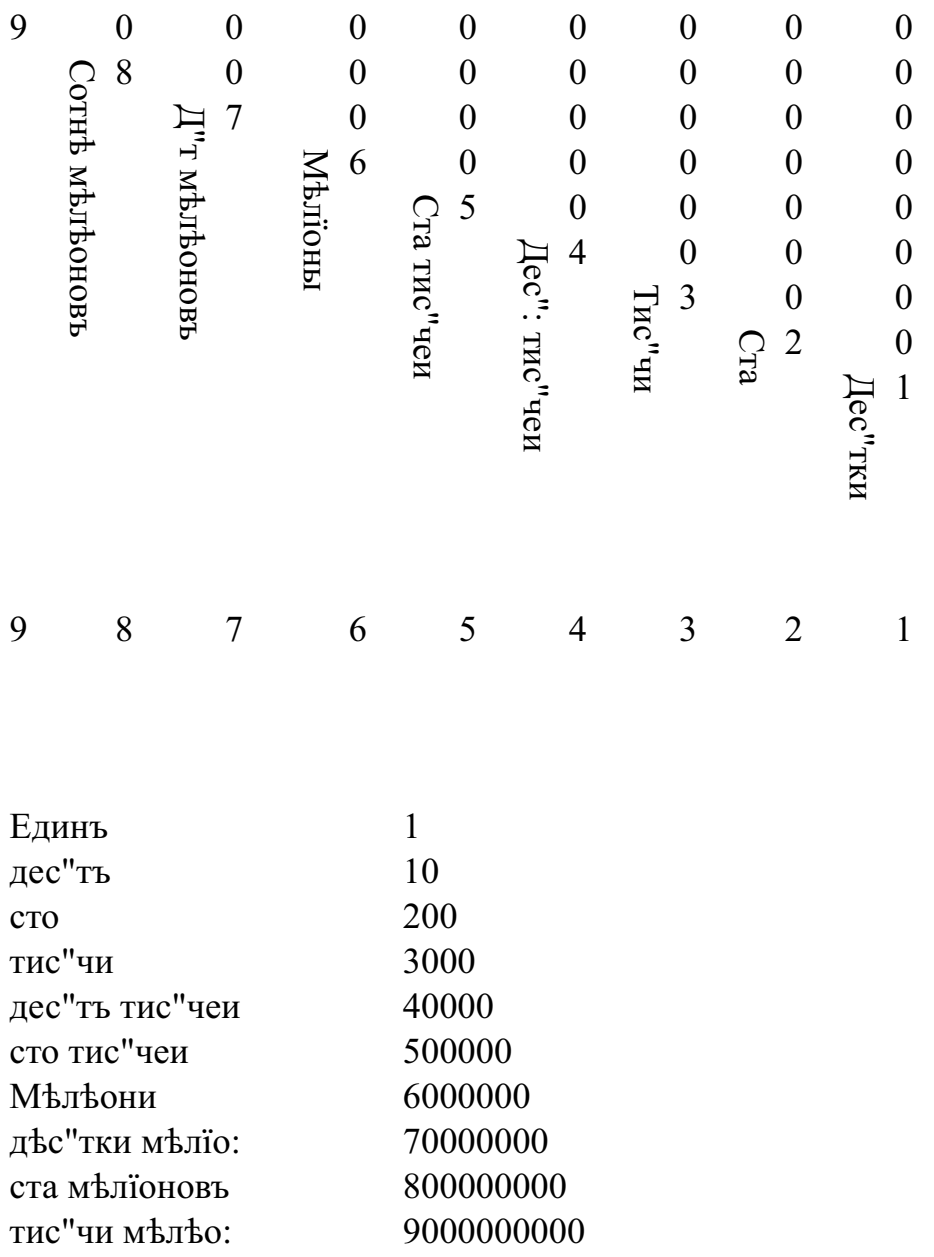

Сіи таблицъ разсмотъвши не трудно будетъ, "къ наиболшаго перечн" силу познати.

ДревнЊишїе Ариөметики ко изчисленїю, сихъ словесъ употребл"лы, начеише $\widetilde{G}$ правои руки, посльднъишои цифри, или нумера, напримъръ въ семъ пе[ре]чнь ${ }^{23}$ :

\footnotetext{
${ }^{23}$ В слові пропущено дві букви.
} 


\begin{tabular}{|c|c|c|}
\hline 18 & 446744 & 073709| \\
\hline $\begin{array}{l}\text { 큘 } \\
\text { : } \\
\text { : }\end{array}$ & 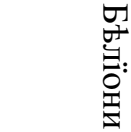 & $\begin{array}{l}3 \\
\text { 芴: } \\
0 \\
0 \\
0\end{array}$ \\
\hline
\end{tabular}

Первїи самъ собою, другїи дес"тки, третїи ста, четвертїи тис"чу держитъ и тои четвертїи, назначивше чертою. $\overline{\mathrm{GD}}$ тогожъ самаго начина" мов"тъ: самъ собою, то естъ тис"чи держитъ, другїи дес"тки тис"чеи, третїи ста, четвертїи тис"чь тис"чеи или мъльони простїе, и проча". А когда уже пришла до ста тис"чеи мъльоновъ, потомъ употребл"и тихъ словъ: бълїони, трилїони, квадрилїони, квђнтилъони, то естъ: сугуббїе трегуббїе четирегуббїе, п"тогуббїе мъльони. Новїе же Ариөметики, вс"кїи перчень раздълөютъ на члени по шести харахтировъ, “ко въ вишшомъ перечнъ, первїи членъ, сотнђ тис"чеи держитъ, въ другомъ сотнъ тис"чеи мЂлђоновъ, въ третомъ стнъ тис"чеи бълъоновъ, и проча^, зри перечень:

\begin{tabular}{|c|c|c|c|}
\hline 345623 & 435562 & 213400 & 211223 \\
\hline 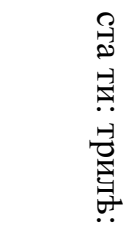 & 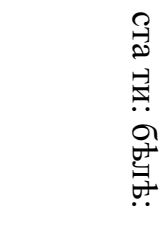 & 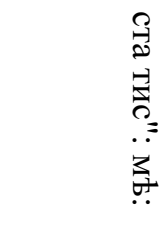 & 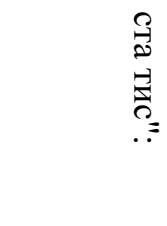 \\
\hline
\end{tabular}

\section{G сложенїю аданцїи.}

Сложенїе естъ многихъ числъ единаго вида, вь многихъ перчн"хъ, во единъ перечень собранїе Фднаго вида: тоесть подобную вещъ с подобною себъ, и писать и слагатъ: напримњръ рубль зъ рублемъ, ефимки со ефимками, золотие со золотими.

Когда перчнь станешъ росписовать, подписоваи пр"мохонко числа подъ подобними сеьъ: одинове подъ одинокими, дес"тки подъ дес"тками и проча". А будетъ въ которомъ перечнъ менше харахтировъ “къ въ другомъ, то то мЂсто празное оставл"и, токмо берегис", дабы простїе под простими, а дес"тки подъ дес"тками подписать, а не помъшатъ. Зри примъри А, B, C, D, E:

$\begin{array}{rrrrr}\text { A } 34562 & \text { B } & 43602 & \text { C } & 32545 \\ \underline{24314} & & 36204 & & 1532 \\ 58876 & & \underline{83453} & & \underline{300} \\ & & 163259 & & 34377\end{array}$

\begin{tabular}{rrrr}
\hline D & 963044 & E & 840000 \\
& $\underline{821055}$ & & $\underline{70000}$ \\
\hline 1784099 & & 910000
\end{tabular}


Такъ перечнъ правилно поставивши, подхири, «ко видъть, и начинаи $\overline{\mathrm{G}}$ правї» руки $\vec{G}$ посльдн»го зо спода харахтирь, слагать, дружку з дружкою, напримьрь, вь Перечнъ А. Последнїи естъ с правои руки харахтиръ 4 , надъ нимъ 2 , того будктъ шестъ, тие 6 нипиши под лънЊею пр»мо подъ 4, потомъ сльдуютъ 1 и 6 , того всего 7, тие 7 такожъ пиши подъ льнъею прАмо: подъ однимъ поступи даль, знаидешъ 3 и 5 , то зложивше въ купу, будетъ 8 , і тїе пиши подъ исподни подъ 3 , и дальи слагаи 4 зь 4 будетъ 8 , и тїе по презнему 8 , напиши подъ ленею подъ 4 пр»мо, на остатки 2 а 3 сложи будетъ 5 , напиши 5 под ленею пр»мо подъ 2 , станетъ одинъ, со двохъ перечень, 58876 п»тьдес»ть тис»чеи, и осмъ, въсьмъсотъ съмдес»тъ и шесь.

СлучитсА, когда въ перечнАхъ нЊкоторихъ будутъ цифри, а во другихъ сверху, или со испода, пр»мо надъ ними числителнїе, и ти дълаи по вишеученномъ, а цифри брось, зри примъръ В.

А когда слчитъс», что, два харахтири произидутъ изь сложенї», то ти последнЊиши пиши заразъ под испода, под ленъю, пр»мо подъ тими числами, которие ти слагаль, а первїи харахтиръ 1 на умъ держи, и ховаи ко на сльдующимъ вь р»дъ нумерамъ. Зри тоиже самїи примъръ В, и проччї», а посльдующимъ образомъ слагаи, мовАчи: 3 а 4 есть 7 до того два естъ 9 тїе 9 обычно подпиши подъ льнеею, и слагаи наступуючїи рөдъ, гдђ знаидешъ 5 и двђ цифри которїе весма повергаютс», того рады самїе п»ть пиши под ленъю, а слагаи посльдующї 4 со 2 будетъ шестъ, к тому ещо шестъ, того станетъ дванаиц» 12 , посльднъишїи харахтиръ 2 , напиши обично под лЊнею, а одинъ бери на умъ, илико насльдующимъ числамъ, которїе треба слагать придаи, «ко здесъ суть 3 а 1 що на умъ, сутъ 4, до того 6 будеть 10, к тому 3, стане 13, и ти 3 по презнему напиши под исподни, а 1 знавъ ховаи, 1 прилагаи къ сльдующимъ числамъ, тоестъ до 8, стане 9. Придаи еще три, и четири, стане 16 , два харахтири, которїе в р»дъ напиши оба подъ ленъю, понеже окончалесъ и нъ дла чого болше ховать, або на умъ брать.

Случитс»: что во всђхъ перечн»хъ самїе цифри або ноль, нђсколко ихъ будетъ, токмо по однои цифрђ под льнею пиши, а числителнїе харахтиры, по вишше наученному зложивъ, поъписоваи обично.

Повъренїе сложенїя, праведно или погрђшенно сложенїе удълано такъ познаешъ: зо всъхъ перечнеи котрїе надъ ленъею или чертою сто"тъ, втхири або вимажи по дев"ти, а що зостанеть менше 9, тое ти напиши на сторону, по тому жъ вимазоваи зъ генералного перечн". Которіи подъ льнъею такожъ по 9, будетъ либъ осталниихъ подобенъ первому, върное изчисленїе, будеть болше или менше, погрђшенно.

\section{GО вичитанїю или субтракцїи.}

Вичитанїе, естъ меншаго числа, зъ болшаго Фౌ"тїе, по которомъ С̄"тю нужда знать, сколко вь шсталихъ будетъ. "ко 2 вичитавши зъ 4, останетъ 2 . Тимже переченъ вс"кїи, меншїи, вичитоваетъс" зъ болшаго. Разумъи, меншои перечнь, быть такій, въ которомъ, хот"и бы всъ харахтири болшїе были, $\bar{G}$ верхн"го, когда толко сподниіи харахтиръ з львои руки на первомъ мъсть положенъ, есть меншїи $\widehat{\bigodot}$ верхн"го. Зри примърь F. G.

\section{F. 34567}

G. 16698

Здесь въ перечнъ G. хот"и всь нумеры, болшїе сутъ $\overline{\mathrm{GD}}$ верхн"го, Фнако есть меншїи онъ, бо первїи з львои руки на исподъ, меншои естъ $\widetilde{G}$ верхн"го, тоестъ 1 $\overline{\mathrm{G}}$ трохъ. 
Вичитанїе вь такыихъ правилахъ остоитъс", далъ “ кому вь заемъ 8456 рублеи,

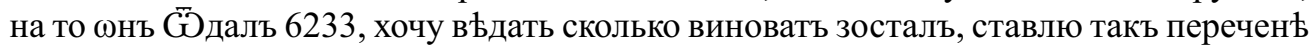
дано вь заими 8456 на то Б̄ дано $\underline{6233}$

зосталь виненъ 2223

А вичитоваю симъ образомъ, правилно росписавъ въ заемъ данїе и $\overline{\mathrm{G} д а н і ̈ е, ~}$ подхири, и мовъ 3 вз"ль $\overline{\mathrm{G}} 6$, зостануть 3 , тїе 3 напиши подъ ленью пр"мо подъ 3 , зновъ 3 зъ 5, остане 2, напиши 2 зновъ подъ ленью, потомъ 2 зъ 4 вичитаи остануть 2, которїе 2 по презнему, просто напиши подъ ленъею подъ 4, на остатку вичитаи 6 зъ осми, зостанутъ 2, тие написавши чинно подъ ленъею, маешъ переченъ 2223, сколко зостаосль ${ }^{24}$ виновато, зъ заемнихъ денегъ.

СлучитсА: что вь перечнъ верхнемъ, и исподнемъ, ровное число. Подъ ровнїмъ будетъ написанное “ко 5 под 5, 6 подъ 6, 0 подъ 0 зри примьръ К. Въ токовомъ случаю, вс"гди подъ ленъею пишетсл 0. Бо когда 5 вичитаешъ и Б̄Иимешъ зъ 5, або 0 зъ 0 , того ради 0 пишетъсА. А такъ вичитоваи.

К. 34506

$\underline{10506}$

24000

Вз"вши 6 зъ 6, нъчого не остаетсА, длА того пиши 0. Потомъ 0 зъ 0 нъчого 3 ньчого, такожъ нъчого не зостаетъ, дл" того пиши 0. Потомъ вичитоваи 0 зъ 4, останутъ 4, то ти пиши пр"мо подъ исподи подъ 4, на остатокъ 1 зъ 3 останутъ 2, тїе 2 подписавъ подъ ленъю. Будетъ осталнїи переченъ 24000. Когда вь нижнемъ перечнь будетъ 0, а въ верху надъ нолемъ, въ перечнь верхнемъ, числителнїи, “ко то подъ 4, вичитоваи нолъ зъ четирихъ, зостанутъ 4, бо ежели ньчого не берешъ $\overline{\mathrm{G}}$ четирохъ, то цълнї 4 зостаютъс" пиши тїе самїе подъ ленъею, а дълаи по вишше наученому, “къ в томЂже перечнь К. вьшше научено.

А будет случитс", въ вишнемъ перечнъ сто"ти нолъ цифра, или меншои нумеръ, а въ нижнемъ пр"мо подъ меншимъ болшїи харахтиръ, то ти такъ дълаи; зри примъръ насто"щїи а вичитоваи так:

453240

$\underline{132833}$

320407

3 взать зъ цифри не можна, то ти бери зъ дес"тка заивого, будьто у тебе на сторонь лежить, 10 зостануть 7, бо 3 зъ 10 вз"тши зостаютъ 7, тие 7, подпиши подъ ленью, пр"меико подъ 3. По тому 3 которїе, (несуь болше тры, но четыри, бо за заивїи дес"токъ, вс"гдаи, одна ко посльдующои дружки, прирастаетъ) вз"вши зь 4, зостане ньчого, дл" того пр"мо подъ 3 напиши 0. Вичитоваи 8 зъ 2, не мощно, дл" того зъ заивого вичитаи дес"тка, по презнему, зостанутъ два, тие 2 придаи кь верхнимъ 2 зъ которихъ не моглесъ вичитатъ, стане 4, тие 4 напиши подъ ленъю подъ 8, а вичитоваи 3, [бо вс"гди одна приростоваеть кь споднои посльдующои личбъ, запожиченїи дес"токъ:] зь трохъ нъчого не останеть, того ради пиши подъ ленью 0. Дальи вичитати $3 \overrightarrow{\mathrm{G}} 5$ зостануть 2 , пиши в р"дъ по прежнему 2 подъ ленью, знова 2 зъ 4, зостануть два, цЊлїи переченъ 22047. Лудшои пам"ти ради, накрепко витверды сїи правила вичитанї": 1 правило, когда зь

${ }^{24}$ Так в тексті. 
цифри вичитать надобно, а не можна, то вичитаи зь дес"тка заивого, за которїи дес"токъ Фдна на исподъ кь посльдующои прирастаетъ. Правило 2, когда харахриръ, нумеръ, личбу, болшую з меншои надобно вичитать, а не можна, такожъ $з$ дес"тка заивого вичитоваи, а что останетъ, то зложи въ купу, зь тоею, зъ которои не моглесь, вичитовать, а то все зложенное нипиши подъ ленъю, а за тои заивїи дес"токъ прирастоваетъ одинъ до последуючого нумера, которїи надлежитъ вичитовати. Зри примъръ вишше.

Вичитані" повъренїе таковое: зложи оба споднїе перечнъ, то естъ, что С̄ дано, и что з осталнихъ, когда подобнїи перечень будетъ верхнему, тому что ва заими дано, върное повъренї, а когда что С̄Мънно, по погрђшенно въ чомъ.

GD умноженїю, мултиплькацїи.

Умноженїе: естъ единаго числа, чрезъ другое число помноженїе, напримъръ: трижди, по трижди, будетъ 9. Дважди по два, будет четиры, дважди по п"тъ, будетъ 10, шестю по шестъ, будетъ 36 и: проча".

Во умноженїю токмо два перечн" сто"тъ, первїи називаетъс" умножаемїми, которого помножити надобъ, другїи, которимъ помножаютъ умножитель: напимъръ купилъ хто Фвецъ 1323, кажда овца по три злотихъ, умножаемїи есть Фвци, умножителъ естъ 3 зло:[тых] $]^{25}$ и так ко умноженїю, перечнь сто"тъ: зри В.

В 1323 умножаемїи

- 3 помножитель

3969 продукть або произведенъ

Третого которїи зь умноженї", происходитъ, називаютъ продуктомъ. А умножаютъ симъ образомъ: Зри В, 3 по трижди, буде 9, которїе пр"мо подъ ленъею подъ помножителемъ пиши, зновъ 3 по два, будетъ 6, напиши за 9 подъ 2, зновъ 3 по 3 б[уд]етъ ${ }^{26} 9$ напиши за 6, пр"мо подъ 3, на остатокъ 3 по Фдиножди стало 3, напиши и тїе 3 за 9 подъ 1, стала вс" сума надлежащам за юбци 3969.

Случитьс" что умножителъ будетъ мъти, болше «къ одинъ харахтиръ, то ти всьми по единцемъ умножаи, а каждую льчбу подъ своимъ умножителемъ, пр"мо, подъ ленъею подписоваи. Зри примъръ С, колко часовъ въ едномъ году.

С 365 днь въ году

$\frac{24}{1460}$ часи во дню единомъ

730

8760 толко часовъ въ единомъ году.

Такъ умножать надобно. 4 по 5, буде 20, ноль напиши подъ хиривши, пр"мо подъ умножителемъ, а 2 сховаи, “къ в сложенїю учено, на сторону, зновъ 4 по 6, стало 24, кь тому 2, на сторонь схованїе придаи, буде 26, шесть напиши подъ ленью за нолемъ, а 2 зновъ сховаи, потомъ мовъ 4 по 3 стане 12, к тому 2 схованїе, стане 14 . Первїи переченъ 1460. Начинаи умножаты другимъ умножителемъ, тоесть 2. А мовъ 2 по 5, естъ 10, ноль пиши, пр"мо подъ 2, а 1 ховаи по прежнему, 2 по 6 будетъ 12, Фдна схована стало 13, три подъпиши, а 1 ховаи, на остатокъ 2 по 3 будетъ 6, единъ схованъ, естъ, 7, напиши 7 под ленъю подъ 1. Стане другїи перечень 730, которїе сложи, въ едено, стане 8760 часовъ въ годђ. Такъ дълаи во всьхъ случа"хъ. Хот"и наиболше умножитель мьти будеть харахтировъ, зри перечень D.

\footnotetext{
${ }^{25}$ В тексті слово скорочено: «зло».

${ }^{26}$ Склад в тексті пропущено.
} 
$\mathrm{D}$

\begin{tabular}{|c|c|}
\hline 7238 & льта $\overline{G D}$ сотворенї" мира \\
\hline 8760 & часи еднаго года \\
\hline 434280 & \\
\hline 50666 & \\
\hline 57904 & \\
\hline 67331340 & часи $\overline{\mathrm{G}}$ со:[творения мира] $]^{27}$ мира \\
\hline
\end{tabular}

Когда умножитель будеть мъти на конци цифру Фдну або болше, то всъ напиши в р"дъ подъ ленъю, а числителними умножаи, зри D. Когда будетъ умножаемїи и умножитель имњти ноль, то всь в р"дъ подъпиши, зри Е.

E $\quad 3040600$

$\frac{200}{408120000}$

Случитс" что умножителъ 0 имъти будетъ посерединъ, то ти цифру Фдну прамо подъ нею, подъ ленью написавши, умножаи, по сльдующимъ харахтиромъ, и заразъ за нею начинаи писать. Зри примьръ F.

$\mathrm{F}$

335

201

335

6700

67335

Случитс^ что умножитель, бидетъ ${ }^{28} 1$, а при немъ то ти токмо цифри до умножаемаго припиши, понеже Фдна, нъ дълитъ, нъ умножаетъ. Скорьишаго ради умножанїа витверди наизусть сию таблицу.

\begin{tabular}{|l|l|l|l|l|l|l|l|l|l|}
\hline 1 & 2 & 3 & 4 & 5 & 6 & 7 & 8 & 9 & 10 \\
\hline 2 & 4 & 6 & 8 & 10 & 12 & 14 & 16 & 18 & 20 \\
\hline 3 & 6 & 9 & 12 & 15 & 18 & 21 & 24 & 27 & 30 \\
\hline 4 & 8 & 12 & 16 & 20 & 24 & 28 & 32 & 36 & 40 \\
\hline 5 & 10 & 15 & 20 & 25 & 30 & 35 & 40 & 45 & 50 \\
\hline 6 & 12 & 18 & 24 & 30 & 36 & 42 & 48 & 54 & 60 \\
\hline 7 & 14 & 21 & 28 & 35 & 42 & 49 & 56 & 63 & 70 \\
\hline 8 & 16 & 24 & 32 & 40 & 48 & 56 & 64 & 72 & 80 \\
\hline 9 & 18 & 27 & 36 & 45 & 54 & 63 & 72 & 81 & 90 \\
\hline 10 & 20 & 30 & 40 & 50 & 60 & 70 & 80 & 90 & 100 \\
\hline
\end{tabular}

Когда хочешъ а знати сколко естъ п"ть по 5, ищы 5 зь боку, и сверху, по тому спускаис" пр"мо по комркамъ, обща коморка противо 5 покаже, 25 столко 5 по 5, ти удњлаетъ, такъ и прочїе.

Повъраютъ умноженїе, череъ дъленїе праведно, или погрђшно, о чомъ въ дьленїю.

${ }^{27}$ В тексті слово скорочено: «со:».

${ }^{28}$ Так в тексті, повинно бути «будетъ". 


\section{G дъленъю або дивъзїи.}

ДҺленїе есть “кого перечнл, сумми, или инихъ “кихъ вещеи, на многихъ раздьленїе, вь дъленїю токмо два перечнъ, единъ називаютъ дивъдендусъ, раздъл"емїи, другїи дивъзоръ раздьлителъ, напримъръ, дано 642 рублА, на трохъ салдатовъ, раздъл"еми есть рубль, раздълителъ салдати, бо рубль на нихъ надобно подълиты, третїи которїи зъ дъленїл походитъ, називаютъ квоциесъ, коликїи, и пишетсл на сторонъ за чертою, изъ боку.

Дьленї^ правила суть сїи: 1 раздђлителА 3 львого боку, подъ самую шстатную льчбу подъписуютъ, когда токмо неболшїи естъ $\bar{G}$ первого харахрита раздъл"емаго, заразъ подъ другимъ подпиши, и въ шбохъ ищы, сколко разъ мощно вз"ть, а пиши за ленъю зь боку, зри I. II.

2 написавши коликаго, умножи раздълителемъ, и продуктъ вичитаи з раздъл"емаго, மсталнїе пиши на верху, зри I. II.

3 зъ раздълителемъ вс"гди Фднимъ мъстомъ дальи поступи, поки до самаго конца, подъ раздъл"емаго не прїидешъ.

4 за ленью въ коликомъ (хот"и и мощно вз"ть) болше дев"ти не пишетъс^.

5 случитсл что со раздълителемъ подїидешъ поъ меншїи харахтиръ, або подъ 0, або цъле поъ мъсто празне, то ти до коликаго 0 приписавъ, самъ далъ поступы Фднимъ мъстомъ, зъ дълителемъ, зри III.

Когда дълителъ болше харахтировъ и мњти будетъ “къ Фдинъ, то всь треба умножать коликимъ, и вичитовать, зри III.

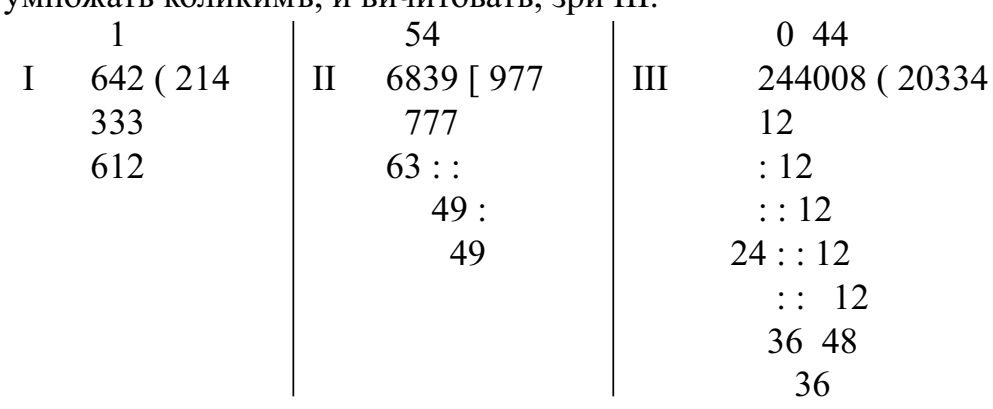

Написавши раздълөемаго 642, подъпиши подъ нимъ делителА 3, и ищи сколко мощно по 3 взАтъ зъ шести, знаидешъ 2 рази, ти 2 напиши з боку за ленью, по тому мовъ два рази по три стане 6 тїе 6, подъпиши подъ дълител", вичитаи изъ раздълАемаго, изъ 6 не остане нъчого, поступи дальи еднимъ мъстомъ зь дьлителемъ подъ 4 мовъ 3 въ 4 единъразъ, припиши до коликого а мовъ единъ разъ по 3 буде 3, три вз"вши зъ 4 மстане 1 , пиши надъ 4 , а чотири похири, поступи дальи дьлителемъ подъ 2, и ищи сколко по 3, изъ 12 мощно вз"ть, знаидешъ 4, раза тие 4, пиши до коликаго, а мовъ 3 по 4 стало 12 подпиши 12 подъ дълителА и вичитоваи, 2 зъ 2 вз"вши не остане нъчого, 1 зъ 1 тожъ не остане нъсчого. Сталъ квоциенсъ або коликїи 224 рублеи, по столко вс"кому достанетъсћ, если хто на трохъ дастъ 642, такъ дълаи и въ прочїихъ случа"хъ.

Повъренїе: дълителемъ умножи коликаго, если раздъл"емїи произїиде, добре дълано,иначеи; погрђшено.

Умноженіе повьришъ, дъли продуктъ або произведеннаго умножителемъ, когда произїиде умножаемїи, вЂрно, иначе погрђшено. 


\section{Увъщанїе.}

На сеи годъ доволно, аще плоды въ люд"хъ сихъ трудовъ увидимъ, не умедлимъ обширне и болше написать, бо есть въ готовости, цъла Ариөметика, Математика и Архитектура воеенна.

\section{REFERENCES}

Biryukov, G. (2009). Nachalo russkogo knigopechataniya v Kenigsberge. Retrieved from https://ruskline.ru/analitika/2009/11/12/nachalo_russkogo_knigopechataniya_v_ kenigsberge/ [in Russian].

Bondar, N. (2016). Ridkisni kalendarni vydannya pershoyi polovyny XVIII st. KyyevoPechers'koho druku z fondiv Natsional'noyi biblioteky Ukrayiny imeni V. I. Vernads'koho, Ukrayins'ke nebo 2 - Studiyi nad istoriyeyu astronomiyi v Ukrayini: zb. nauk. pr., Lviv, 648-657. [in Ukrainian].

Bykova, T. A., Gurevich, M. M. (1958). Opisaniye izdaniy, napechatannykh kirillitsey: 1689 - yanvar' 1725, Moskva-Leningrad: Izd-vo Akad. nauk SSSR [in Russian].

Depman, I. Ya. (1965). Istoriya arifmetiki, Moskva: Prosveshcheniye [in Russian].

(1912). Die Matrikel der Albertus-Universität zu Königsberg in Preussen. Pr. II. Band: Die Immatrikulationen von 1657-1829, Leipzig: Duncker \& Humblot [in German].

(1719). Grecheskiy, rimskiy i yevreyskiy kalendar' na leto Gospoda nashego Iisusa Khrista, Chernigov [in Slavic].

Gubin, A. B. (1994). Pravoslaviye v Vostochnoy Prussii (Zapiski) [Orthodoxy in East Prussia (Notes)], Zapad Rossii, (4 (12), 7-19 [in Russian].

Isaievych, Ya. D. (2004). Drohobych u XVII-XVIII st.: z dzherel pro pobut i kul'turu mis'koho naselennya, Drohobyts'kyy krayeznavchyy zbirnyk, Drohobych: Kolo, 198-207 [in Ukrainian].

Isaievych, Ya. D. (2014). Yuriy z Drohobycha, Ukrayins'ke nebo 2. Studiyi nad istoriyeyu astronomiyi $v$ Ukrayini: zb. nauk. pr., Lviv, 490-507. [in Ukrainian].

(1726). Kalendar na 1727 god, Kenigsberg: Typ. Vasiliya Korvin Kvasovs'kogo [in Slavic].

(1729). Kalendar na 1730 god, Kenigsberg: Typ. Vasiliya Korvin Kvasovs'kogo [in Slavic].

Kameneva, T. N. (1964). Tipografiya na Levoberezh'ye Ukrainy, 400 let russkogo knigopechataniya. 1564-1964, Moskva: Nauka, 221-224. [in Russian].

Karatayev, I. P. (1861). Khronologicheskaya rospis' slavyanskikh knig, napechatannykh kirillovskimi bukvami. 1491-1730, Sankt Peterburg: tip. Akademii nauk [in Russian].

Kolyada, H. I., Isaievych, Ya. D. (1965). Drukarska sprava na zakhidnoukrayinskykh zemlyakh (XVI-XVIII st.), Knyha i drukarstvo na Ukrayini, Kyiv: Naukova dumka, 42-69 [in Ukrainian].

Olyanchyn, D. (1937). Pam'yatky iz mynuloho ukrayins'koho dukhovno-kul'turnoho zhyttya v Kenihsberzi, Naukovyy zbirnyk $v 30$ richnytsyu naukovoyi pratsi prof. d-ra Ivana Ohiyenka, Warszawa, 92-108 [in Ukrainian].

Pekarskiy, P. P. (1862). Nauka i literatura v Rossii pri Petre Velikom, Sankt Peterburg: izdaniye Tovarishchestva «Obshchestvennaya pol'za», (1) [in Russian].

Rovinskiy, D. A. (1881). Russkiye narodnyye kartinki, Sankt Peterburg: Imp. Akad. nauk, 1881, (2) [in Russian].

Shustova, Yu. E. (2017). Kiyevskiye izdaniya Kalendarey 30-kh godov XVIII v. iz sobraniya Rossiyskoy gosudarstvennoy biblioteki kak istochniki po istorii ekologicheskikh i 
yestestvenno-nauchnykh znaniy, Chelovek i priroda: Istoriya vzaimodeystviya, istochniki i informatsionnyye resursy, vizual'nyye obrazy i issledovatel'skiye praktiki, Moskva, 35-54 [in Russian].

Sopikov, V. S. (1906). Opyt rossiyskoy bibliografii, Sankt Peterburg: A. S. Suvorin, (5) [in Russian].

Sopikov, V. S. (1821). Opyt rossiyskoy bibliografii, ili Polnyy slovar sochineniy i perevodov, napechatannykh na slavenskom i rossiyskom yazykakh ot nachala zavedeniya tipografiy, do 1813 goda, Sankt Peterburg: V tipografii Departamenta vneshney torgovli, (5) [in Russian].

Stroyev, P. M. (1841). Opisaniye staropechatnykh knig slavyanskikh, sluzhashcheye dopolneniyem k opisaniyam bibliotek grafa F. A. Tolstova i kuptsa I. N. Tsarskogo, Moskva: tip. S. Selivanovskogo [in Russian].

Undol'skiy, V. M. (1848). Katalog slavyano-russkikh knig tserkovnoy pechati biblioteki A. I. Kasterina, Moskva: Obshchestvovo istorii i drevnostey rossiyskikh [in Russian].

Undol'skiy, V. M. (1871). Ocherk slavyano-russkoy bibliografii, s dopolneniyami A. F. Bychkova i A. Viktorova, Moskva: Moskovskiy publichnyy i Rumyantsevskiy muzei [in Russian].

\section{Yuliya SHUSTOVA. Unknown «Arithmetic» of the Ukrainian scientist Vasyl Korvin- Kvasovsky as a part of the Königsberg Calendar for 1730}

The article is devoted to the unknown work on arithmetic of the Ukrainian scientist, mathematician, author of printed Cyrillic calendars Vasyl Korvin-Kvasovsky. He printed his calendars in Chernihiv and Koenigsberg. These books contained calendar and chronological information for the current year, and also included astrological, prognostic texts and texts on educational topics. In his own printing house in Königsberg, Corwin-Kwasowski included in the Calendar for 1730 a manual for teaching arithmetic «Arithmetic, or digital science». This is the first printed textbook on arithmetic in Ukrainian by a Ukrainian scientist from the Ukrainian lands. The article attempts to reconstruct the biography of Vasyl Korvin-Kvasovsky. He studied at the Königsberg Academy and was a professor at the Universities of Krakow and Prague. This study examines his work as an author and publisher of calendars. It was important to publish in 1719 the Calendar compiled for the «Chernihiv Meridian». The last period of Corwin-Kwasowski's life was associated with Königsberg, where he held a number of respectable positions, received the privilege of operating his own printing house, where he published calendars. There are three known Königsberg editions of Corwin Kwasowski's calendars - for 1727 and two editions for 1730 (engraved and typesetting). The article provides a detailed description of the typesetting Calendar for 1730, which contains «Arithmetic». «Arithmetic, or digital science» is considered, which is the first part of the textbook. It consists of five sections. The first considers a numerical digit and numbers. The following are the rules for calculating four mathematical operations - addition, subtraction, multiplication, division. The article compares the basic concepts in the «Arithmetic, or digital science» of Corvin-Kvasovsky and «Arithmetic» of Leontiy Magnitsky (Moscow, 1703). Based on the analysis of the given explanations and examples, a conclusion is made about Vasyl KorvinKvasovsky as a talented teacher who embodied his teaching experience in a textbook on arithmetic. In the Appendix to the article, for the first time, the text of the first printed «Arithmetic», written in Ukrainian by Drohobych scientist Vasyl Korvin-Kvasovsky, is published in full.

Keywords: Vasily Korvin-Kvasovsky, calendar, history of mathematics, arithmetic, Ukrainian old printed books, Konigsberg Cyrillic typography. 